\title{
Hospital Policy in Providing Medicines outside the Provisions of Permenkes No. 28/2014 to BPJS Participant Patients
}

\author{
Joko Wahono \\ Program Studi Magister IImu Hukum Kesehatan \\ Fakultas Hukum Universitas Hang Tuah Surabaya \\ E-mail: jokowahonoMH@gmail.com
}

How to cite (in APA style):

Wahono, J. (2021). Hospital Policy in Providing Medicines outside the Provisions of Permenkes No. 28/2014 to BPJS Participant Patients. Jurnal Hukum Prasada, 8(1), 1-7. doi: https://10.22225/jhp.8.1.2877.21-29

\begin{abstract}
This study analyzes criminal, civil and administrative legal responsibility for hospital policies in administering medicines outside the provisions of Permenkes Number 28 of 2014 . This research is a normative legal research using a statutory approach (statue approach) and a conceptual approach (conceptual approach). The document study is used to collect legal material. The legal materials in this study consist of primary legal materials, secondary legal materials and tertiary legal materials. The health service that is often provided by the hospital to the public is a form of health service that is carried out outside the provisions of the regulations that must be carried out in accordance with the prevailing laws and regulations. The results showed that the implementation of medicine services for BPJS participant patients at the hospital was not in accordance with the Minister of Health Regulation No. 28 of 2014, BPJS participant patients were prescribed medicines outside the National Defense Forces to buy medicines at outside pharmacies at their own expense. The hospital can be held responsible for criminal, civil and administrative law. Therefore, it is hoped that hospitals and health workers, especially doctors, in carrying out their duties and obligations must comply with the prevailing laws and regulations in order to avoid the risk of legal liability.
\end{abstract}

Keywords: Fornas; Health BPJS; Hospital Policy; Legal Accountability

\section{INTRODUCTION}

Basically, the development of the health sector is aimed at increasing awareness, willingness and ability to live a healthy life for everyone. In addition, optimal health status is one of the elements of welfare as mandated by the preamble to the 1945 Constitution (hereinafter referred to as the 1945 Constitution). Health as a Human Right must be realized in the form of providing various health efforts to the entire community through the implementation of quality and affordable health development (Abbas, 2008).

The importance of national health is one of the goals of national development. These basics are obtained from the mandate of the 1945 Constitution which is contained in Article $28 \mathrm{H}$ of the 1945 Constitution, which states that: "administrators of health efforts are regulated by the government, so there is a need for public health insurance, this is carried out by the government by implementing the National Health Insurance System (Kurnia, 2007).

In Article $28 \mathrm{H}$ paragraph (1) of the 1945 Constitution states that: "Every person has the right to live in physical and spiritual prosperity, to have a place to live and get a good and healthy living environment and the right to obtain health services". Article $28 \mathrm{H}$ paragraph (2) states: "Everyone has the right to receive special facilities and treatment to get the same opportunities and benefits in order to achieve equality and justice". In Article $28 \mathrm{H}$ paragraph 
(3) it is stated that: "Everyone has the right to social security which enables his complete development as a dignified human being".

In the National Social Security System (also known as SJSN), as a State program, aims to provide assurance of social protection and welfare for all people as mandated in Article 28 $\mathrm{H}$ and Article 34 of the 1945 Constitution in Article 34 paragraph (2) of the 1945 Constitution, states: a social security system for all the people and empower the weak and underprivileged people according to human dignity". Article 34 paragraph (3) of the 1945 Constitution states that: "the state is responsible for the provision of proper health service facilities and public service facilities". In Article 34 paragraph (4) of the 1945 Constitution, it is stated that: "further provisions regarding the implementation of this article are regulated in the Law".

In contrary, aplenty of cases found in the society such as in South Barito Regency (Barsel), Central Kalimantan Province, many of the BPJS participant patients have complained about the services at the Jaraga Sasameh Regional General Hospital in (hereinafter referred to as RSUD) Buntok which are always told to buy medicines' through a doctor's prescription at the pharmacy outside, on the pretext that the medicine stock at the pharmacy at the local hospital had run out. This condition, of course, is considered to be very detrimental to the BPJS participants, both inpatients and outpatients. The service of Social Security Administrator for Health (Hereinafter referred to as BPJS) participant patient should refer to Permenkes RI No. 28 of 2014 the RSUD provides medicines for BPJS participants. Nurul Hikmah, a representative council of Barsel, said: "even though the medicines available at the pharmacy at the local hospital have run out, it means that the RSUD must provide medicine s for BPJS participants (Iswani, 2020).

The other cases at the Jantung Harapan Kita Hospital, which was mentioned by the Daily Chair of the Yayasan Lembaga Konsumen Indonesia (YLKI), Tulus Abadi, still received complaints regarding the problems of participants of the National Health Insurance (hereinafter referred to as $\mathrm{JKN}$ ) especially regarding queues and complaints for purchasing medicines outside the hospital. Patients who are JKN participants should not spend money to pay off medicines. Not only that, there are also patients who only get half of their medicine rationing rights, should have received 30 pills of medicine for one month, apparently only getting 15 from the hospital on the grounds of the BPJS provisions, so the rest of the patients have to pay for themselves. Tulus hopes that with the ready-to-help service, BPJS is expected to solve existing problems quickly (Hartono, 2019).

Medicine administration for BPJS participants has been regulated in Permenkes No. 28/2014 on medicine services, medicine provision and medicine use. Medicine services for JKN participants at health facilities refer to the list of medicines listed in the National Formulary (hereinafter referred to as Fornas) and medicine prices listed in the medicine ecatalog. In the event that the type of medicine is not available in Fornas and the price is not in the e-catalog, then the procurement can use another procurement mechanism in accordance with statutory regulations, namely Presidential Regulation Number 70 of 2012 concerning Second Amendment to Presidential Regulation Number 54 of 2010 About Government Procurement of Goods / Services.

Furthermore, the provision of medicines at health facilities is carried out by referring to the Fornas and medicine prices listed in the medicine e-catalog, while regarding the use of medicines outside Fornas in the implementation of health services, the use of medicines is adjusted to standard treatment and in accordance with applicable regulations. If in the provision of health services, the patient needs medicines that have not been listed in Fornas, then this can be provided with the provisions stipulated in the Minister of Health Regulation No. 28/2014, concerning medicine services, medicine supply and medicine use with the following conditions:

a. The use of medicines outside the National Formulary in First Level Health Facilities can be used if it is in accordance with medical indications and in accordance with medical service standards whose costs are included in capitation and may not be 
borne by participants.

b. The use of medicines outside the national formulary at the Advanced Referral Health Facility is only possible after receiving a recommendation from the Chair of the Pharmacy and Therapy Committee with the approval of the Medical Committee or the Head / Director of the Hospital whose costs are included in the standard rates used by the Hospital as a reference claim fees to the government as BPJS at the expense of BPJS participants and may not be borne by participants.

Medicine providers often do not meet medicine needs according to statutory regulations, for example in the case of BPJS patients being prescribed medicines to be purchased at their own expense. If the availability of medicines for BPJS patients is empty, the doctor can prescribe medicines to the patient to be purchased at another pharmacy at the hospital's expense or use the patient's funds first, which will later be reimbursed by the hospital by showing the receipt for the purchase of the medicine from the pharmacy outside the hospital.

Based on the results of the survey by the researcher using the central online questionnaire as a BPJS Complaint Handling Information Service (also known as PIPP) staff, the researcher conducted direct interviews with the patient, by taking 5 outpatient and inpatient samples every 3 days. It was found as much as $40 \%$ of the visiting patients to the Jombang District Hospital was given a prescription for medicines outside the National Formulary.

The conformity of the prescription with the National Formulary research was carried out on the prescription of outpatient JKN patients in the internal clinic, heart, children, gynecology, nerves, skin and genital poly. The analysis showed that out of 1,524 prescriptions there were 381 medicines prescribed (40\%) and there were 1,143 medicine items according to the national formulary $(60 \%)$.

Table 1. Compatibility of Prescription Writing with the National Formulary (Fornas) Prescribing Percentage

\begin{tabular}{|l|c|}
\hline Fornas & $60 \%$ \\
\hline Non Fornas & $40 \%$ \\
\hline Total & $100 \%$ \\
\hline
\end{tabular}

The data above is a prescription in the hospital. The medicine prescribed must comply with the national formulary. This is done to improve the quality of pharmaceutical installation services (Pemberi Informasi Penanganan Pengaduan, 2019). In connection with these facts, it shows that the rights of BPJS Kesehatan participants are not yet fully fulfilled in providing services according to the agreement text in the form of a Memorandum of Understanding (MoU), both in facilities and services to BPJS participants at the Hospital. Based on the description of the problems that befell BPJS participant patients who are prescribed outside the provisions of Permenkes No. 28 of 2014, then this current research aims to analyze criminal, civil and administrative legal responsibility for hospital policies in administering medicines outside the provisions of Permenkes Number 28 of 2014.

\section{METHOD}

This type of research is a normative juridical research that is research that seeks solutions to legal issues that arise to provide prescriptions (Marzuki, 2005). In this study, researcher conducted a systematic study of the legal norms contained in statutory regulations and court decisions related to criminal liability (Mertokusumo, 2007). The approach used in this research is a statutory approach namely an approach that examines legal principles, legal norms and statutory regulations as well as a conceptual approach (Marzuki, 2005) namely identifying basic basic definitions in law, namely legal subjects, rights and obligations, legal events, legal relations and legal objects.

In the process of collecting legal materials, the researcher uses document study, which is to collect primary legal materials in the form of laws and regulations, secondary legal material in the form of law books, journals and literature, and tertiary legal material in the form of legal dictionaries and Indonesian dictionaries. The steps for collecting legal materials 
include: reading, studying, quoting, and comparing legal materials from primary legal materials, secondary legal materials and tertiary legal materials so that they become a single unit so that they are easy to manage. The legal materials that have been collected and obtained for research are then processed systematically and consistently, then analysis is carried out in a series of statements describing the results of the research based on the problem under study. The next step is to carry out a theoretical analysis of these legal materials in order to find, understand and explain criminal, civil and administrative liability in medicine services in hospitals.

\section{RESULTS AND DISCUSSION \\ Criminal Responsibility of Hospital in Health Services}

Criminal action is an act committed in certain circumstances which are declared prohibited by law, which consequently results in corporal and / or moral punishment for the perpetrator. Health is a state of health, whether physically, mentally, spiritually or socially, which enables everyone to live productively socially and economically. One of the facts of the situation behind the formation of the Health Law is that anything that causes health problems to the Indonesian people will cause huge economic losses to the state, and every effort to improve the degree of public health also means an investment for the development of the State that the criminal responsibility of the perpetrator of the crime In the law on health, these are individuals and corporations separately or separately, with the weighting of criminal threats against the corporation.

Hospital is a health service institution that provides complete individual health services that provide inpatient, outpatient and emergency services. One of the facts is the background to the formation of the Hospital Law. In the provisions of Chapter XII, articles 62 and 63, the Hospital Law, stipulates the provisions of criminal acts, as follows:

1. That is imprisoned and fined every person who deliberately operates a hospital does not have a building permit and an operational permit, as regulated in the law on hospitals or its implementing regulations.

2. Whereas in the case of the aforementioned criminal offenses committed by a corporation, in addition to imprisonment and fines against its management, the punishment that can be imposed against the corporation is in the form of a fine with a weighting of 3 (three) times the principal fine.

In addition to the fines mentioned above, the corporation can be subject to additional penalties in the form of business license revocation; and / or revocation of legal entity status. Whereas the criminal responsibility for the perpetrator of a criminal act in the Law concerning health is an individual and a corporation separately or separately from the management, with a weighting on the criminal threat against a corporation other than its management.

The Health Law and the Hospital Law recognize criminal liability separately between individual perpetrators and individuals as corporate managers, with heavy fines against corporations other than their management, so that crimes for perpetrators are clearly differentiated from one another. A person who is accused of committing a criminal act cannot automatically be subject to punishment. Criminal liability as a punishment (punishment) that must be borne (served) by a person / group of people, in connection with their obligations or actions that violate criminal law (Sriyanto, 1993).

The problem of medicine availability is often a complaint for participants of the Health Social Security Administering Body. Starting from medicines not available, to participants who have to buy their own medicine outside of health facilities. In fact, according to Permenkes RI No. 28/2014, BPJS patients have the right to receive medicines listed in the national formulary with an INA-CBG (Indonesia Case Base Groups) package financing model (diagnosis of patient disease according to doctors). If there is medicine outside the national formulary, it can still be given and is the responsibility of the hospital.

Real cases as experienced by Adi; admitted that he had experienced unsatisfactory service because the medicine was not available so he had to buy it himself. He complained 
that he had to buy medicine at another pharmacy because the hospital did not provide the medicine according to the doctor's prescription. "After I was examined by the doctor, I was asked to take the medicine at the counter. But the officer there told me to buy medicine at the pharmacy. The reason is because the supply of medicines in the hospital ran out. When I bought the medicine at the pharmacy, it was expensive," he said. Adi felt that he was not receiving maximum service, even though when using BPJS he no longer paid for his own medicine. He also felt that the services provided were not as good as general patients. ${ }^{1}$

Responding to complaints related to medicine issues, the hospital director revealed that his party always strives to provide optimal service, including the provision of medicines. Medicines needed by patients are readily available in the hospital pharmacy warehouse. "We always try to provide all the medicine needs for the community. Including BPJS patients," he said. The Hospital Director admitted that there were indeed one or two types of medicines that were empty in stock at the hospital. However, the problem is that the national stock of medicines is currently empty throughout Indonesia. Even if the patient is forced to buy medicine outside the hospital because the stock of the medicine has run out or the distributor has not sent it, the cost of the medicine incurred by the patient will be reimbursed by the hospital. "This is in accordance with the MoU between BPJS Kesehatan and Hospitals." So far, BPJS has only collaborated with hospitals regarding the provision of medicines if there are purchases of medicines outside or services outside BPJS. Medicines with certain brands that are not available in health facilities may be purchased from outside. However, it must be with the consent of the patient or family. However, health care providers such as doctors or medical personnel must still offer medicines that are covered and available at health service agencies. Such as clinics, hospitals, or health centers. ${ }^{2}$

Furthermore, the provision of medicines in health facilities is carried out with reference to Fornas and medicine prices listed in the medicine e-catalog, while regarding the use of medicines outside the national formulary in the implementation of health services, medicine use is adjusted to standard treatment and in accordance with applicable regulations. In terms of providing health services, patients need medicines that have not been listed in the national formulary, so this can be provided with the provisions as stipulated in the hospital ministerial regulation must refer to Permenkes No. 28 of 2014 Health No. 28 of 2014, regarding Medicine Services, Provision Medicines and medicine use provided that the use of medicines outside the national formulary in the First Level Health Facilities can be used if it is in accordance with medical indications and in accordance with medical service standards whose costs are included in capitation and may not be borne by participants; The use of medicines outside the national Formulary at the Advanced Referral Health Facility is only possible after receiving a recommendation from the Chair of the Pharmacy and Therapy Committee with the approval of the Medical Committee or the Head / Director of the Hospital, whose costs are included in the INA-CBGs rate and may not be charged to participants.

According to Article 53 paragraph 2 of the Health Law, in carrying out their duties, health workers are obliged to comply with professional standards and respect the rights of patients. Article 147 paragraph 2 of the Health Law, efforts to cure as referred to in paragraph (1) shall be carried out by authorized health personnel and in the right place while respecting the patient's human rights. The current position of the hospital is far different from its previous position where the hospital cannot be held responsible for criminal law because the hospital is still considered a social institution (doctrin of charitable immunity) which, if asked to be responsible for criminal law, will reduce the ability to help patients.

In this case, especially doctors are always faced with legal problems, especially criminal law, in which cases doctors often assume that the responsibility for the consequences of

${ }^{1}$ Wawancara dengan pasien Rawat Jalan Di Rumah sakit Umum Daerah, Pada tanggal 22 februari 2019, Pukul 11.30 WIB.

${ }^{2}$ Wawancara dengan Direktur Rumah sakit Umum Daerah, Pada tanggal 09 maret 2019, Pukul 13.25 WIB 
medical errors must be borne personally. This means that a hospital as a corporation which is a place for doctors to work and provide health services cannot be held criminally responsible. Meanwhile, in other matters, the patient also has the opinion that in the alleged wrong medical action, it is only the responsibility of the doctor's criminal law, because the doctor or dentist is in direct contact with the patient due to the pattern of the therapeutic relationship. The facts in the field are that the hospital's responsibility for the above cases is not in the form of criminal liability. However, the hospital is only responsible in civil terms. In other words, it only provides compensation or returns the cost of medicines to patients participating in the BPJS. Meanwhile, those who carry out criminal responsibility are doctors who handle and provide prescriptions. Doctors are part of a corporation which is a Trinity (including leaders, doctors, and dentists) in a hospital which together functionally lead the hospital and are jointly responsible for medical services to the community. Thus, criminal law as public law can be held accountable by corporations not only to doctors or dentists, but also to hospitals as corporations that are responsible for all wrong medical actions, whether committed by doctors or dentists, or by existing health workers under their supervision of the patient. Apart from doctors, hospitals can also be used as legal subjects because legal entities also act as supporters of rights and obligations.

The hospital as an organization that carries out health service duties is responsible for everything that happens in the hospital, which is generally borne by the director of the hospital concerned. Hospital as a health facility that provides health services to the community has a very strategic role in accelerating the degree of public health. Therefore, hospitals must provide quality services in accordance with established standards and can reach all societies level. Supposedly, the form of hospital criminal responsibility, as a corporation, is criminally responsible for negligence of the hospital which stems from the poor management and management system of the hospital. Hospital criminal liability as a corporation can be implemented by asking the director for criminal responsibility as a representative of the hospital board of directors. However, in practice, what is required to be held responsible for the crime is the doctor who was on duty when the case occurred due to negligence of duty. In addition, law enforcers are also considered to be less observant in resolving cases, only assuming that the hospital is a corporation which only concerns civil matters. Of course, this will create a sense of injustice on the part of the victim's family due to the ineffectiveness of a statutory rule in a criminal incident that hinders the realization of justice and legal certainty. Even though the victim has filed a civil suit, the act committed fulfills a criminal element, so the responsibility that should be carried out is criminal responsibility, namely imprisonment and/or fines.

\section{Civil Responsibilities of Hospital in Health Services}

Acts against the law are regulated in Article 1365 of the Civil Code, which reads: "every act that violates the law and brings harm to others, obliges the person who caused the loss due to his mistake to compensate for the loss." From the sound of the Article, the elements of illegal acts can be drawn as follows: there is an act against the law; there is a mistake; there is a loss, there is a causal relationship between loss and action.

An agreement between a doctor and a patient, or a patient with other health workers, creates legal responsibility in the form of an agreement. The two parties should have fulfilled each other's achievements regarding what had been agreed upon, but in fact there were negligence of health workers due to defaults in the medical services that were carried out.

In terms of hospital responsibility according to civil law, the hospital as a legal entity is responsible as an entity (corporation) and is also responsible for the actions of the people who work therein (respondeat superior) as regulated in articles 1365-1367 of the Civil Code. This responsibility is not only for medical / professional liability, but also for its public liability. This has also been included in Article 190 of the Health Law. Meanwhile, the form of patient protection in terms of responsibility which is based on default actions resulting from not fulfilling the main obligations or additional obligations in the form of obligations for major 
achievements or guarantees / guarantees obligations in the agreement, can be in the form of fulfillment of the engagement which is manifested by concrete actions through the provision of effective services and efficient. Article 1365 of the Civil Code affirms that every act violates the law that brings harm to another person, requires that person to compensate for the wrong caused.

Furthermore, Article 1367 jo. Article 1366 of the Civil Code, that is a person is not only responsible for losses caused by his own actions but also for losses caused by the actions of those who are dependent on him or due to objects under his control. Thus, hospitals and pharmacists are responsible for paying compensation related to losses suffered by BPJS participant patients. In civil law, sanctions are applied in the form of compensation provided by business actors to patients / consumers who have been harmed, namely in the form of refunds, as well as replacement of goods and/or services, health care or provision of compensation.

Hospitals must be responsible under civil law because they fulfill the elements of an illegal act based on the provisions of Article 1365 of the Civil Code if several elements have been fulfilled, namely 1) there is an act (daad) which includes the qualification of an illegal act. 2) There is an error (dolus and / or culpa) in default. 3) There is a loss (schade). BPJS participant patients can choose the demands as stated in Article 1267 of the Civil Code, namely: fulfillment of the engagement; fulfillment of the engagement with compensation; Indemnity; cancellation of mutual agreement. This has become the responsibility of the hospital as a legal entity that is responsible for all activities carried out by health workers in accordance with the 1365 Civil Code that can be prosecuted for damages directly as a party because there is an agreement that is in default. According to Article 1234 of the Civil Code, default is divided into 3 that are give something; do something, and do nothing.

If it is related to legal issues relating to default, do something or do something that should be done by the pharmaceutical sector to patients in the agreement. However, this service deed was not performed. In essence, it is the patient's right to receive medical services. If this is not implemented, the goal of health development to achieve an optimal degree of public health will not be realized because there are some patients whose rights are not fulfilled.

The problem of medicine availability is often a complaint for BPJS Kesehatan participants. Starting from medicines not available, to participants who have to buy their own medicine outside of health facilities. In fact, according to Permenkes RI No. 28/2014, BPJS patients have the right to receive medicines listed in the national formulary with an inasibijis package financing model (diagnosis of patient disease according to doctors). If there is medicine outside the Fornas, it can still be given and is the responsibility of the hospital.

\section{Administration Responsibilities of Hospital in Health Services}

Permenkes number 28 of 2014 chapter IV, the use of medicines outside the national formulary in the FKTP can be used if it is in accordance with medical indications and in accordance with medical service standards whose costs are included in capitation and may not be borne by participants; The use of medicines outside the Fornas at FKRTL is only possible after receiving a recommendation from the Chair of the Pharmacy and Therapy Committee with the approval of the Medical Committee or the Head / Director of the Hospital whose costs are included in the INA CBGs rate and may not be charged to participants.

The elucidation of Article 1 point 2 of the Law on State Administrative Courts laws and regulations are all binding regulations in general issued by the People's Representative Body together with the government, both at the central and regional levels which are also generally binding. The formulation of the meaning of legislation like this includes material and formal definitions. Based on the formulation of the explanation, it can be concluded that the decisions of state administrative bodies or officials are general arrangements (besluit van algemene strekking) including statutory regulations (algemeen verbindende voorschriften).

That everyone is responsible not only for losses caused by their actions, but also for 
losses caused by their negligence, this is clearly contrary to the legal principle underlying health services, namely the principle of being on time so as to cause harm to patients, this is material loss in the form of funds issued for the purchase of medicines outside the hospital pharmacy.

Article 29 of the Health Law explains that in the event that a health worker is suspected of negligence in carrying out his profession, the negligence must first be resolved through mediation. Violation of hospital obligations is subject to administrative sanctions in the form of: warning, written warning; or fines and revocation of hospital license. So, the form of legal remedy available to BPJS participant patients is dispute resolution based on judicial processes. The aggrieved party can sue and/or sue health workers or hospitals, both civil and criminal through an applicable legal process. Civil complaints can be submitted by patients to court based on the losses they have experienced.

The decision of the court is binding. Efforts that can be made for BPJS participant patients for BPJS Kesehatan card holders who feel disadvantaged or dissatisfied in health services can make complaints by contacting the BPJS call center 1500400 or coming directly to the nearest BPJS Kesehatan branch office. So the form of legal remedy available to BPJS participant patients is dispute resolution based on judicial processes. The aggrieved party can sue and/or sue health workers or hospitals, both civil and criminal through an applicable legal process. Civil complaints can be submitted by patients to court based on the losses they have experienced.

In Article 48 of the Law on Social Security Administrator, a unit for service quality control and handling of complaints from Participants is established. So that JKN participant patients who feel their rights have been impaired can make a complaint, if the party who feels aggrieved whose complaint has not been resolved by the unit, then the dispute settlement can be done through a mediation mechanism.

The mediator's assistance agreed by both parties in writing. Dispute resolution through a mediation mechanism, after an agreement between the two parties in writing is final and binding. However, if the complaint by the service quality control unit and the handling of complaints from JKN Participants through a mediation mechanism cannot be carried out, the settlement can be submitted to the district court in the area where the applicant lives.

\section{CONCLUSION}

The hospitals have the responsibility for Criminal, Civil and Administrative Law. The aspect of criminal legal liability at the hospital will occur if the cost of the medicine purchased by the BPJS participant patient is also claimed by the hospital to the BPJS so that it fulfills the elements of a criminal act. Liability under civil law at the hospital can occur if a BPJS patient who buys his own medicine submits a claim to the hospital but the hospital refuses it so that the BPJS patient can file a civil suit in the form of compensation at the hospital because the trial violates the law.

Administrative legal responsibility if the hospital commits administrative violations by employing medical personnel and health workers who do not have registration certificates, work permits, practice permits and violate the limits of their authority. Administrative sanctions can be imposed on doctors who are in the hospital if they do things outside the general rules or practice fraud so that they can be brought to the trial of the code of ethics due to malpractice of prescribing medicines outside the formulary, violating Permenkes No. 28 of 2014 and violating criminal and civil law.

\section{REFERENCES}

Abbas, H. (2008). Pedoman Hak Asasi Manusia bagi Dokter dan Pasien dalam Mencegah Malpraktek Kedokteran. Badan Penelitian dan Pengembangan HAM Departemen Hukum dan HAM RI.

Hartono, S. H. (2019). Dilema Pasien, Pakai BPJS Tebus Obat Masih Bayar dan Terkadang Hanya Diberi Separuh Jatah. GridHEALTH.Id.

Iswani, A. (2020). Pasien Peserta BPJS Mengeluh Menebus Resep Obat di Luar Tanggungan. Bornoe24.Com. 
Kurnia, T. S. (2007). Hak atas Derajat Kesehatan Optimal sebagai HAM di Indonesia. Bandung: Alumni.

Marzuki, P. M. (2005). Penelitian Hukum. Jakarta: Kecana Prenada Media.

Mertokusumo, S. (2007). Penemuan Hukum. Yogyakarta: Liberty.

Sriyanto, I. (1993). Asas Tiada Kesalahan dalam Pertanggungjawaban Pidana dengan Penyimpangannya. Jurnal Hukum \& Pembangunan, 23(2), 158-172.

Pemberi Informasi Penanganan Pengaduan (PIPP). Kabupaten Jombang. Data survey online pusat Survey Rumah Sakit, 12 Maret. 2019

Wawancara dengan pasien Rawat Jalan Di Rumah sakit Umum Daerah, Pada tanggal 22 februari 2019, Pukul 11.30 WIB.

Wawancara dengan Direktur Rumah sakit Umum Daerah, Pada tanggal 09 maret 2019, Pukul 13.25 WIB 